\title{
A Multilevel Study of the Impact of District-Level Characteristics on Texas Student Growth Trajectories on a High-Stakes Math Exam
}

\author{
Shifang Tang * ${ }^{\mathbb{D}}$, Zhuoying Wang $(\mathbb{D}$ and Kara L. Sutton-Jones
}

Citation: Tang, S.; Wang, Z.; SuttonJones, K.L. A Multilevel Study of the Impact of District-Level Characteristics on Texas Student Growth Trajectories on a High-Stakes Math Exam. Mathematics 2021, 9, 8. https:/ / dx.doi. org/10.3390/math9010008

Received: 1 December 2020 Accepted: 20 December 2020 Published: 22 December 2020

Publisher's Note: MDPI stays neutral with regard to jurisdictional claims in published maps and institutional affiliations.

Copyright: () 2020 by the authors. Licensee MDPI, Basel, Switzerland. This article is an open access article distributed under the terms and conditions of the Creative Commons Attribution (CC BY) license (https: / / creativecommons.org/ licenses/by/4.0/).
Center for Research \& Development in Dual Language \& Literacy Acquisition, College of Education and Human Development, Texas A\&M University, College Station, TX 77840, USA; ustop2013wzy@tamu.edu (Z.W.); kara.sutton@tamu.edu (K.L.S.-J.)

* Correspondence: shifangtang03@tamu.edu

\begin{abstract}
Mathematics is a core content area in the science, technology, engineering, and mathematics (STEM) fields and is vital to student learning in the other STEM subjects. The purpose of this study was to investigate the math performance of fifth- and eighth-grade students in 1170 Texas school districts. We conducted growth hierarchical linear modeling in SAS 9.4 in order to explore the effects of time, district-level characteristics, and their interaction on student performance as measured by the State of Texas Assessments of Academic Readiness (STAAR) math test across three performance levels (i.e., approaching, meeting, and mastering grade level) over three academic years: 2016-2019. The overall findings indicated that, over time, Texas school districts improved in the percentage of students who approached, met, and mastered grade-level performance on the STAAR math test. The results also indicated that five district-level variables consistently and significantly impacted Grade 5 and 8 students' math achievement at three performance levels. Significant positive factors included the percentage of English learner students and principal years of experience; significant negative factors were the percentage of economically challenged students, student mobility rate, and teacher turnover rate.
\end{abstract}

Keywords: Texas; mathematics; student achievement; hierarchical linear modeling; fifth grade; eighth grade

\section{Introduction}

Science, technology, engineering, and mathematics (STEM), as essential parts of any well-rounded education, have received increasing global attention [1]. As a core STEM subject, math bolsters the other STEM disciplines [2-4]. A solid grounding in math supports students' learning and understanding of scientific and technological literacy and content [5]. In general, math learning develops students' problem-solving and critical-thinking skills in school settings [6] and prepares them for life and work beyond school [7].

It has been observed that students suffer a sharp drop in their academic achievement as they matriculate between schools (i.e., elementary to middle school, middle to high school) [8] due to changes in course structure (one teacher to multiple subject-area teachers) and changes in life and school experience [9]. The middle school years are a particularly critical period for students' math learning since their math achievement at this stage has a significant impact on their enrollment and success in advanced math courses in high school and beyond [10,11]. However, U.S. students' math performance at the secondary level has been a great concern [12]. According to the Condition of Education 2020 [13], $20 \%$ of fourth-grade and $30 \%$ of eighth-grade students failed to reach a basic level in math on the National Assessment of Educational Progress (NAEP) in 2017. This situation did not change in 2019. 
It is worth noting that on the same assessment, English learners (ELs) and economically challenged (EC) students significantly underperformed compared with their non-EL and non-EC peers. This phenomenon is consistent with researcher observations that student factors, such as students' socioeconomic status [12,14-16] and English language proficiency (ELP) [17], significantly impact students' subject learning, including math. Furthermore, school factors, such as teachers' qualifications [18], teaching experience [19], and turnover rate [20], can also influence students' academic performance.

Therefore, in this study, we conducted a data-driven analysis of fifth- and eighth-grade students' math performance in Texas, the second largest and second most populous U.S. state, to explore the impact of district-level variables on students' math achievement at two transitional grade levels. The following research questions guided this study:

1. Was there a significant improvement of Texas school districts' fifth- and eighth-grade students' performance on the State of Texas Assessments of Academic Readiness (STAAR) math test from 2016 to 2019 ?

2. What was the impact of district-level characteristics (i.e., the percentage of economically challenged students, percentage of English learners, principals' average number of years of experience, teachers' average number of years of experience, teacher turnover rate, student mobility rate, teacher-student ratio, and percentage of full-time teachers) on students' performance on the STAAR math test, when other variables are controlled for?

\subsection{Texas State Standards for Math Instruction}

Math is a required subject for all grade levels from elementary through high school in Texas. According to the Texas Education Code [21], the Texas Essential Knowledge and Skills (TEKS) for Math is guided by college and career readiness standards to achieve educational excellence. "By embedding statistics, probability, and finance, while focusing on computational thinking, mathematical fluency, and solid understanding, Texas will lead the way in mathematics education and prepare all Texas students for the challenges they will face in the 21st century" [21].

Grade 5 students are expected to understand and master 10 types of knowledge and skills in math:

- Applying math process standards to learn and demonstrate math problems;

- Following math standards to understand the relationship between rational numbers and place value;

- $\quad$ Computing positive rational numbers to solve math problems;

- Developing concepts of math equations and expressions;

- Classifying two-dimensional figures with graphic organizers based on properties;

- Understanding and quantifying volume;

- Solving math problems involving measurement with appropriate approaches and tools;

- Identifying attributes and process of a coordinate plane;

- Analyzing math problems via data collection, organization, and interpretation; and

- Managing personal financial resources for security reasons [21].

Likewise, Grade 8 students are expected to understand and master 12 types of knowledge and skills in math:

- $\quad$ Learning and justifying math knowledge;

- Using and representing real numbers in different forms;

- Describing dilations with proportional relationships;

- Clarifying proportional and non-proportional relationships with slope;

- Developing basic concepts of function with proportional and non-proportional relationships;

- Making connections between math relations and geometric formulas;

- $\quad$ Solving math problems with geometry knowledge; 
- Solving problems with one-variable equations;

- Developing basic concepts of simultaneous linear equations with multiple representations;

- Generalizing and explaining transformational geometry concepts;

- Describing data with statistical procedures; and

- Thinking and solving problems in an economical manner [22].

\subsection{State of Texas Assessments of Academic Readiness}

The state-mandated student assessment-the STAAR—was first implemented in 2012 to measure student knowledge and skills in reading, math, social studies, writing, and science, as defined in the TEKS. The STAAR math test is administered annually in Grades 3-8. Since academic year 2016-2017, the four-descriptor system has been applied to classify students' performance levels from high to low: masters, meets, approaches, and does not meet grade level.

According to the Texas Education Agency (TEA) [23], students are classified as "masters grade level" if they are going to succeed in the next grade level with limited academic intervention. Students who achieve this level on the STAAR Grade 5 math test are expected to solve application problems involving various operations, solve multi-step problems with one variable, and apply geometry and measurement concepts. Students who achieve this level on the STAAR Grade 8 math test are expected to describe the linear relationship between proportional and non-proportional numbers, model one-variable inequalities, and describe the effects of rotations, reflections, and dilations with algebraic representations.

Students are classified as "meets grade level" if they have high potential to succeed in the next grade level with some short-term, targeted academic intervention. Students who achieve this level on the STAAR Grade 5 math test are expected to solve application problems with positive rational numbers, use equations to solve multi-step problems, and solve problems involving perimeter, area, and volume. Students who achieve this level on the STAAR Grade 8 math test are expected to use different forms of numbers, solve math problems on rotations, reflections, and dilations, and model one-variable equations.

Students are classified as "approaches grade level" if they are likely to succeed in the next grade level with targeted academic intervention. Students who achieve this level on the STAAR Grade 5 math test are expected to identify numerical relations and prime and composite numbers, and use models to solve multiplication and division problems. Students who achieve this level on the STAAR Grade 8 math test are expected to identify proportional relationships and congruence transformations, solve problems on surface area, volume, interest, and savings, and determine slope and growth on a graph or table.

Students are classified as "does not meet grade level" if they are unlikely to succeed in the next grade level without significant and ongoing academic intervention.

\subsection{Student- and District-Level Factors That Influence Student Subject Learning}

Student- and district-level factors influence student academic achievement. In a review of 100 studies on math achievement in secondary school [12], the researchers concluded that "the most important problem in mathematics education is the gap in performance between middle- and lower-class students and between White and Asian American students and African American, Hispanic, and Native American students" (p. 887). EC students are more likely to live in less supportive educational environments for content learning [24] and have been observed to underperform compared to their peers from more advantaged socioeconomic backgrounds [25]. Moreover, students' English language proficiency is also positively related to their content learning, including science and math [26].

Besides student-level factors (i.e., SES, ELP), researchers have suggested that states consider the potential impact of school- or district-level factors, such as teacher qualifications, educational resources, and students' learning outcomes [27]. For example, some scholars have attributed students' low math achievement to an inadequate supply of qualified teachers, considering nearly half of middle school math teachers were not undergrad- 
uate math majors or minors [18]. Other commonly cited variables that affect students' academic outcomes are teacher experience $[19,28]$, teacher turnover rate $[20,29]$, principal experience [30,31], teacher-student ratio [32], student mobility rate [33], and full-time teachers [34].

Researchers have conducted a limited number of quantitative studies that comprehensively investigated the impact of student, teacher, and principal characteristics on students' math performance using a large-scale dataset. Although they examined multiple variables related to principals [31,32], teachers [19], or students [34], or just one teacher variable $[29,30]$, to the best of our knowledge, there is no study investigating how students' math achievement is impacted by all these factors combined. Moreover, none of these studies focused on Texas. Some of the studies were conducted in the northeastern United States [28,29,33], or outside of the country entirely [19,32], which means different educational contexts from Texas school districts. Therefore, it is worthwhile to explore how student, teacher, and principal variables together influence students' academic performance in Texas.

\subsection{Empirical Studies on Student- and District-Level Factors on Texas Middle School Students' STEM Achievement}

The math performance of Texas middle school students on the NAEP [35] is neither disastrous nor stellar; it is in line with the national average. Compared with other U.S. states, Texas has a unique student population. In Texas, $18 \%$ of public school students are identified as English learners [13], the second highest number in the nation. Over $60 \%$ of Texas students are economically challenged [36].

Based on our literature review, there were limited empirical studies on how student factors impact their STEM performance on state standardized tests. For example, Anderson [37] investigated the impact of socioeconomic status (SES) on Grade 5 and 8 students' science and math performance on the STAAR administered in academic years 2011-2015. He found that EC students consistently and significantly underperformed compared to their non-EC peers in both Grades 5 and 8, with a small to moderate effect size.

Wang et al. [38] examined multiple district-level factors (i.e., student mobility rate, percentage of ELs, teacher-student ratio, teacher education level, teacher salary, and teacher turnover rate) on students' STAAR science performance. They identified student mobility rate, percentage of ELs, and teacher turnover rate as factors significantly influencing students' science achievement. However, how these factors impact students' math achievement remains unknown.

\section{Materials and Methods}

\subsection{Research Design and Data Collection}

For our study, we utilized a longitudinal research design. We were interested in looking at fifth- and eighth-grade students' math performance in Texas across three school years and at the impact of district-level variables on students' math achievement over that time period.

According to TEA [39], there were 1203 school districts in 2016-2017. In this study, a total of 1170 public school districts were included for final analysis due to data availability. District-level STAAR math test data for fifth- and eighth-grade students were downloaded from the publicly available database, Texas Assessment Management System (TAMS). Since TEA adopted new descriptors to describe student performance levels in 2017, we collected district-level STAAR math scores spanning three academic years: 2016-2017, 2017-2018, and 2018-2019. Our study population consisted of all fifth- and eighth-grade students in the state of Texas during that time span, and our sample were those Grade 5 and 8 students whose data were aggregated at the district level and were available in TAMS. District-level demographic data from academic year 2016-2017 (i.e., percentage of economically challenged students, percentage of ELs, student mobility rate, principal years 
of experience, teacher years of experience, teacher turnover rate, teacher-student ratio, and percentage of full-time teachers) were collected from the TEA annual reports.

The state of Texas classifies a student as an English learner when: "(a) a language other than English is used as the primary language at home, and (b) the student's English language proficiency is determined to be limited by a Language Proficiency Assessment Committee (LPAC) or as indicated by a test of English proficiency" [40]. An economically challenged student is one who is eligible for free or reduced-price meals through the National School Lunch and Child Nutrition Program [41]. The teacher turnover rate represents the percentage of teachers from fall 2015 who were not employed by the district in fall 2016 [42]. The student mobility rate is the count and percentage of students who have been enrolled at a school for less than $83 \%$ of the academic year (i.e., missed six or more weeks) [42].

\subsection{Data Analysis and Model Specification}

By utilizing district-aggregated, fifth-grade and eighth-grade STAAR math achievement data, we examined Texas students' math performance. A growth hierarchical linear model (GHLM) was adopted to analyze the multilevel longitudinal dataset collected for fifth- and eighth-grade students across three academic years: 2016-2019. GHLM was chosen due to its flexibility in dealing with missing data [43] and with unbalanced data and unequal spacing conditions [44]. In this study, we produced two models for analysis: (a) a conditional growth model (time model with grade level [Grades 5 and 8]) and (b) a full model with all district-level variables included. The two models were repeated three times, using approaches, meets, and masters grade level as the outcome. SAS 9.4 was utilized to complete the above analyses. Model specification is described as follows:

Model 1: conditional growth model. A time variable was added as a level-1 variable. Students' grade level was coded as a categorical variable and added as a level-2 predictor, with Grade 8 as the reference group. The model explores the estimated average growth rate regarding the percentage of students classified at each performance level for districts in each year for Grades 5 and 8, respectively.

Level-1

$$
\text { Math }_{\mathrm{ij}}=\beta_{0 \mathrm{j}}+\beta_{1 \mathrm{j}} \mathrm{TIME}_{\mathrm{ij}}+r_{i j}
$$

Level-2

$$
\begin{gathered}
\beta_{0 j}=\gamma_{00}+\gamma_{01} \text { GradeLevel }_{j}+\mathfrak{u}_{0 j} \\
\beta_{1 j}=\gamma_{10}
\end{gathered}
$$

Mixed Model

$$
\text { Math }_{\mathrm{ij}}=\gamma_{00}+\gamma_{01} \text { GradeLevel }_{j}+\gamma_{10} \text { TIME }_{\mathrm{ij}}+\mathrm{u}_{0 \mathrm{j}}+\mathrm{r}_{\mathrm{ij}}
$$

Math $_{\mathrm{ij}}$ is the percentage of students classified at a performance level at time $i$ for school district $j$;

$\beta_{0 j}$ is the expected mean percentage of students classified at a STAAR performance level for an individual school district $j$;

$\gamma_{00}$ is the difference between Grade 5 and Grade 8 students in school districts regarding the percentage of students classified at a STAAR performance level in academic year 2016-2017; $\gamma_{10}$ is the expected mean growth rate across districts during academic years 2016-2017 to 2018-2019 for Grade 5 and 8 students;

$\mathrm{u}_{0 \mathrm{j}}$ is the district-level random effect for $\gamma_{00}$;

$\mathrm{r}_{\mathrm{ij}}$ is the deviation of time $i$ from district $j$ 's mean percentage of students classified at a STAAR performance level (i.e., a within-district random effect).

Model 2: full model. Based on the conditional growth model, we further incorporated district-level covariate factors, including economically challenged student percentage, EL student percentage, principal years of experience, teacher years of experience, teacherstudent ratio, teacher turnover rate, student mobility rate, and percentage of full-time 
teachers in academic year 2016-2017. This model examines how district-level variables impacted student math achievement from a longtudinal perspective.

Level-1 Model

$$
\operatorname{Math}_{\mathrm{ij}}=\beta_{0 \mathrm{j}}+\beta_{1 \mathrm{j}} \mathrm{TIME}_{\mathrm{ij}}+\mathrm{r}_{\mathrm{ij}}
$$

Level-2 Model

$$
\begin{gathered}
\beta_{0 j}=\gamma_{00}+\gamma_{01} \text { GradeLevel }_{j}+\gamma_{02} \text { EC }_{j}+\gamma_{03} \text { EL }_{j}+\gamma_{04} \text { PrincipalEx }_{j} \\
+\gamma_{05} \text { TeacherEx }_{j}+\gamma_{06} \text { TSRatio }_{j}+\gamma_{07} \text { Turnover }_{j} \\
+\gamma_{08} \text { SMobility }_{j}+\gamma_{09} \text { FullTime }_{j}+u_{0 j} \\
\beta_{1 j}=\gamma_{10}+\gamma_{11}
\end{gathered}
$$

Mixed Model

$$
\begin{aligned}
& \text { Math }_{i j}=\gamma_{00}+\gamma_{01} \text { GradeLevel }_{j}+\gamma_{02} \text { EC }_{j}+\gamma_{03} \text { EL }_{j}+\gamma_{04} \text { PrincipalEx }_{j} \\
& +\gamma_{05} \text { TeacherEx }_{j}+\gamma_{06} \text { TSRatio }_{j}+\gamma_{07} \text { Turnover }_{j} \\
& +\gamma_{08} \text { SMobility }_{j}+\gamma_{09} \text { FullTime }_{j}+u_{0 j}+r_{i j}
\end{aligned}
$$

Time was a level-1 predictor with the first time point (academic year 2016-2017) as the reference time point. In total, three time points were included in the analysis. Model fit was tested via the difference of deviance (-2loglikelihood) of two models with the following formula: $\chi^{2}=$ Deviance $_{\text {Reduced }}-$ Deviance $_{\text {Full. }}$ The difference between two chi-square values greater than 3.84 indicates a significant overall model improvement [45]. Therefore, if the difference of deviance between Model 1 and Model 2 is larger than 3.84, Model 2 is statistically significantly different from Model 1, which indicates a better model fit for Model 2.

\section{Results}

Descriptive statistics of Texas school districts' Grade 5 and 8 STAAR math performance from 2016 to 2019 are reported in Table 1. Table 2 displays the descriptive statistics of school district characteristics as collected in academic year 2016-2017.

Table 1. Descriptive statistics of school districts' fifth-grade and eighth-grade STAAR math achievement by performance level for academic years 2016-2019.

\begin{tabular}{ccccccccccc}
\hline & & \multicolumn{3}{c}{$\mathbf{2 0 1 6 - 2 0 1 7}$} & & \multicolumn{2}{c}{ 2017-2018 } & \multicolumn{3}{c}{ 2018-2019 } \\
\hline & & N & Mean & S.D. & N & Mean & S.D. & N & Mean & S.D. \\
\hline \multirow{2}{*}{ Math Approaches \% } & Grade 5 & 1140 & 78.91 & 14.52 & 1146 & 83.23 & 13.01 & 1148 & 81.13 & 14.20 \\
& Grade 8 & 1109 & 71.98 & 16.95 & 1113 & 75.50 & 16.21 & 1120 & 79.67 & 14.57 \\
\hline \multirow{2}{*}{ Math Meets \% } & Grade 5 & 1140 & 43.31 & 18.34 & 1146 & 52.19 & 18.31 & 1148 & 50.93 & 18.30 \\
& Grade 8 & 1109 & 38.63 & 20.23 & 1113 & 44.07 & 21.06 & 1120 & 51.27 & 20.29 \\
\hline \multirow{2}{*}{ Math Masters \% } & Grade 5 & 1140 & 19.45 & 12.49 & 1146 & 24.13 & 14.16 & 1148 & 30.02 & 15.43 \\
& Grade 8 & 1109 & 10.47 & 10.97 & 1113 & 11.86 & 12.11 & 1120 & 13.83 & 12.47 \\
\hline
\end{tabular}

$\mathrm{N}=$ Number. S.D. $=$ Standard deviation.

Research Question 1: Was there a significant improvement of Texas school districts' fifth- and eighth-grade students' performance on the STAAR math test from 2016 to 2019?

To answer the first research question, we added time as a level-1 predictor in Model 1 (the time model). The parameter estimates of the time model by STAAR performance levels are displayed in Table 3. Time was a statistically significant predictor on students' math achievement in both grade levels (Grades 5 and 8 ) and for the three performance levels (approaches, meets, and masters). On average, in academic year 2016-2017, there were $78.25 \%, 43.38 \%$, and $20.91 \%$ of fifth-grade students approaching, meeting, and mastering grade level, respectively. In the same year, there were $73.18 \%, 39.53 \%$, and $8.48 \%$ eighthgrade students approaching, meeting, and mastering grade level, respectively. In 2016-2019, 
the percentage of students approaching grade level increased by $2.47 \%$ each year, and by $5.06 \%$ and $3.52 \%$ for meeting and mastering grade level, respectively.

Table 2. Descriptive statistics of school district-level characteristics in academic year 2016-2017.

\begin{tabular}{cccc}
\hline & $\mathbf{N}$ & Mean & S.D. \\
\hline EC \% & 1162 & 0.59 & 0.21 \\
EL \% & 1162 & 0.11 & 0.13 \\
Principal Average Years & 1161 & 18.45 & 6.93 \\
Teacher Average Years & 1161 & 11.49 & 3.38 \\
Teacher Turnover Rate & 1155 & 20.45 & 10.22 \\
Student Mobility Rate & 1162 & 0.15 & 0.09 \\
Teacher-student Ratio & 1161 & 13.08 & 2.90 \\
Full-time Teacher \% & 1161 & 0.53 & 0.07 \\
\hline
\end{tabular}

Table 3. Parameter estimates of fixed and random effects of Model 1 by performance level.

\begin{tabular}{|c|c|c|c|c|}
\hline & Fixed Effect & Coefficient (SE) & $t(d f)$ & $p$ \\
\hline \multirow{7}{*}{ Approaches Grade Level } & Intercept $\left(\gamma_{00}\right)$ & $73.18(0.41)$ & $179.66(1936)$ & $<0.001$ \\
\hline & Time $\left(\gamma_{10}\right)$ & $2.47(0.15)$ & $16.03(5570)$ & $<0.001$ \\
\hline & Grade Level & $5.07(0.25)$ & $20.02(5612)$ & $<0.001$ \\
\hline & Random Effect & Variance & Standard Error & $z$ \\
\hline & Intercept $\left(\mathrm{u}_{0 \mathrm{j}}\right)$ & 127.21 & 6.18 & $20.60(<0.001)$ \\
\hline & Residual $\left(\mathrm{r}_{\mathrm{ij}}\right)$ & 106.74 & 2.02 & $52.72(<0.001)$ \\
\hline & Fixed Effect & Coefficient (SE) & $t(d f)$ & $p$ \\
\hline \multirow{7}{*}{ Meets Grade Level } & Intercept $\left(\gamma_{00}\right)$ & $39.53(0.52)$ & $75.87(2045)$ & $<0.001$ \\
\hline & Time $\left(\gamma_{10}\right)$ & $5.06(0.20)$ & $24.96(5598)$ & $<0.001$ \\
\hline & Grade Level & $3.95(0.33)$ & $11.83(5642)$ & $<0.001$ \\
\hline & Random Effect & Variance & Standard Error & $z$ \\
\hline & Intercept $\left(\mathrm{u}_{0 \mathrm{j}}\right)$ & 201.79 & 9.79 & $20.60(<0.001)$ \\
\hline & Residual $\left(\mathrm{r}_{\mathrm{ij}}\right)$ & 184.91 & 3.50 & $52.85(<0.001)$ \\
\hline & Fixed Effect & Coefficient (SE) & $t(d f)$ & $p$ \\
\hline \multirow{6}{*}{ Masters Grade Level } & Intercept $\left(\gamma_{00}\right)$ & $8.48(0.35)$ & $24.54(2207)$ & $<0.001$ \\
\hline & Time $\left(\gamma_{10}\right)$ & $3.52(0.14)$ & $24.80(5602)$ & $<0.001$ \\
\hline & Grade Level & $12.43(0.23)$ & $53.18(5652)$ & $<0.001$ \\
\hline & Random Effect & Variance & Standard Error & $z$ \\
\hline & Intercept $\left(\mathrm{u}_{0 \mathrm{j}}\right)$ & 82.73 & 4.12 & $20.06(<0.001)$ \\
\hline & Residual $\left(\mathrm{r}_{\mathrm{ij}}\right)$ & 90.86 & 1.72 & $52.87(<0.001)$ \\
\hline
\end{tabular}

Research Question 2: What was the impact of district-level characteristics (i.e., the percentage of economically challenged students, percentage of English learners, principals' average number of years of experience, teachers' average number of years of experience, teacher turnover rate, student mobility rate, teacher-student ratio, and percentage of fulltime teachers) on students' performance on the STAAR math test, when other variables are controlled for?

Model fit analysis revealed that Model 2 was significantly different from Model 1 at three performance levels, with a chi-square value of model change of 1307.5 for approaches grade level, 1115.2 for meets grade level, and 954.6 for masters grade level-higher than the critical value of 3.84. The parameter estimates of Model 2 by STAAR performance level are displayed in Table 4.

The results of Model 2 indicated that time remained a statistically significant predictor regarding the percentage of students rated as approaching, meeting, and mastering grade 
level. We found that the percentage of EC students, teacher turnover rate, and student mobility rate had a significant negative impact on the percentage of students at each performance level on the STAAR math test. For example, a one-unit increase in EC students resulted in a $19.6 \%$ decrease in students rated as approaching grade level in the STAAR math test. A one-unit increase in the teacher turnover rate resulted in a $0.19 \%$ decrease in students rated as approaching grade level, and a one-unit increase in student mobility rate resulted in a $52.58 \%$ decrease in students rated as approaching grade level. Moreover, the percentage of ELs and principal years of experience had a significant positive impact on the percentage of students approaching, meeting, and mastering grade level. For example, a one-unit increase in the percentage of ELs led to an increase of $8.13 \%, 17.34 \%$, and $12.61 \%$ in students approaching, meeting, and mastering grade level, respectively. The same pattern was identified in the impact of principal years of experience on performance levels, particularly at the higher levels, such as meeting and mastering grade level.

Furthermore, we found that the percentage of full-time teachers and teacher-student ratio were not statistically significant predictors of any STAAR performance level. Teacher years of experience had a statistically significant impact on approaching grade level only.

Table 4. Parameter estimates of fixed and random effects of Model 2 by performance level.

\begin{tabular}{|c|c|c|c|c|}
\hline & Fixed Effect & Coefficient (SE) & $t(d f)$ & $p$ \\
\hline \multirow{14}{*}{ Approaches Grade Level } & Intercept $\left(\gamma_{00}\right)$ & $88.01(4.26)$ & 20.67 (1175) & $<0.001$ \\
\hline & Time $\left(\gamma_{10}\right)$ & $2.46(0.15)$ & $16.00(5559)$ & $<0.001$ \\
\hline & Grade Level & $4.98(0.25)$ & $19.72(5625)$ & $<0.001$ \\
\hline & $\mathrm{EC} \%$ & $-19.61(1.69)$ & $-11.61(1164)$ & $<0.001$ \\
\hline & EL \% & $8.13(2.58)$ & $3.15(1176)$ & 0.0017 \\
\hline & Principal Average Years & $0.09(0.04)$ & $2.38(1168)$ & 0.0176 \\
\hline & Teacher Average Years & $0.24(0.11)$ & $2.23(1158)$ & 0.0258 \\
\hline & Teacher Turnover Rate & $-0.19(0.03)$ & $-6.38(1178)$ & $<0.001$ \\
\hline & Student Mobility Rate & $-52.58(3.07)$ & $-17.12(1259)$ & $<0.001$ \\
\hline & Teacher-student Ratio & $0.01(0.11)$ & $0.06(1173)$ & 0.9505 \\
\hline & Full-time Teacher \% & $6.52(4.29)$ & $1.52(1174)$ & 0.1284 \\
\hline & Random Effect & Variance & Standard Error & $\mathbf{z}$ \\
\hline & Intercept $\left(\mathrm{u}_{0 \mathrm{j}}\right)$ & 50.36 & 2.91 & $17.31(<0.001)$ \\
\hline & Residual $\left(\mathrm{r}_{\mathrm{ij}}\right)$ & 105.76 & 2.01 & $52.68(<0.001)$ \\
\hline \multirow{15}{*}{ Meets Grade Level } & Fixed Effect & Coefficient (SE) & $t(d f)$ & $p$ \\
\hline & Intercept $\left(\gamma_{00}\right)$ & $55.67(5.80)$ & $9.59(1183)$ & $<0.001$ \\
\hline & Time $\left(\gamma_{10}\right)$ & $5.06(0.20)$ & $24.90(5568)$ & $<0.001$ \\
\hline & Grade Level & $3.85(0.33)$ & $11.54(5630)$ & $<0.001$ \\
\hline & $\mathrm{EC} \%$ & $-33.78(2.30)$ & $-14.66(1173)$ & $<0.001$ \\
\hline & EL \% & $17.34(3.52)$ & $4.92(1184)$ & $<0.001$ \\
\hline & Principal Average Years & $0.14(0.05)$ & $2.66(1176)$ & 0.0080 \\
\hline & Teacher Average Years & $0.25(0.15)$ & $1.70(1167)$ & 0.0899 \\
\hline & Teacher Turnover Rate & $-0.28(0.04)$ & $-6.85(1186)$ & $<0.001$ \\
\hline & Student Mobility Rate & $-36.79(4.18)$ & $-8.80(1265)$ & $<0.001$ \\
\hline & Teacher-student Ratio & $0.21(0.15)$ & $1.44(1182)$ & 0.151 \\
\hline & Full-time Teacher \% & $9.62(5.84)$ & $1.65(1182)$ & 0.0999 \\
\hline & Random Effect & Variance & Standard Error & $z$ \\
\hline & Intercept $\left(\mathrm{u}_{0 \mathrm{j}}\right)$ & 95.76 & 5.39 & $17.78(<0.001)$ \\
\hline & Residual $\left(\mathrm{r}_{\mathrm{ij}}\right)$ & 184.79 & 3.51 & $52.72(<0.001)$ \\
\hline
\end{tabular}


Table 4. Cont.

\begin{tabular}{|c|c|c|c|c|}
\hline & Fixed Effect & Coefficient (SE) & $t(d f)$ & $p$ \\
\hline \multirow{14}{*}{ Masters Grade Level } & Intercept $\left(\gamma_{00}\right)$ & $18.59(3.97)$ & $4.68(1179)$ & $<0.001$ \\
\hline & Time $\left(\gamma_{10}\right)$ & $3.52(0.14)$ & $24.70(5563)$ & $<0.001$ \\
\hline & Grade Level & $12.38(0.23)$ & $52.88(5628)$ & $<0.001$ \\
\hline & EC \% & $-23.94(1.58)$ & $-15.20(1168)$ & $<0.001$ \\
\hline & EL \% & $12.61(2.41)$ & $5.24(1180)$ & $<0.001$ \\
\hline & Principal Average Years & $0.10(0.04)$ & $2.57(1172)$ & 0.0102 \\
\hline & Teacher Average Years & $0.07(0.10)$ & $0.71(1162)$ & 0.4753 \\
\hline & Teacher Turnover Rate & $-0.16(0.03)$ & $-5.84(1182)$ & $<0.001$ \\
\hline & Student Mobility Rate & $-12.86(2.86)$ & $-4.49(1263)$ & $<0.001$ \\
\hline & Teacher-student Ratio & $0.19(0.10)$ & $1.84(1177)$ & 0.0657 \\
\hline & Full-time Teacher \% & $5.58(4.00)$ & $1.39(1178)$ & 0.1633 \\
\hline & Random Effect & Variance & Standard Error & $z$ \\
\hline & Intercept $\left(\mathrm{u}_{0 \mathrm{j}}\right)$ & 43.99 & 2.53 & $17.42(<0.001)$ \\
\hline & Residual $\left(r_{i j}\right)$ & 90.86 & 1.72 & $52.70(<0.001)$ \\
\hline
\end{tabular}

\section{Discussion}

In this study, we adopted a growth hierarchical linear model to investigate how Texas districts supported fifth- and eighth-grade students' math learning over a three-year period. We explored two research questions in this study. The first research question examined an average growth rate of all school districts in terms of students' math achievement reported across three performance levels: approaches, meets, and masters grade level. The second research question asked to what extent district-level characteristics affected the student growth trajectories across three performance levels.

The overall findings indicated that Texas school districts improved in the percentage of students who approached, met, and mastered grade-level performance on the STAAR math test over time. This positive finding indicated that Texas schools have been successful in supporting students at all performance levels in math learning. Although NAEP data indicated that $10 \%$ more eighth-grade students failed to reach a basic level on the NAEP as compared with fourth-grade students, our analysis of Texas school districts revealed that a gap existed in the 2016-2017 school year and was almost closed in 2018-2019.

Because math is essential to learning content areas in science and technology [2], closing the gap in math achievement could improve student academic achievement across subjects. Furthermore, the significant increase in the percentage of students approaching, meeting, and mastering grade level over time in the transitional grade levels (i.e., Grades 5 and 8) implied that Texas schools have been successful in helping students transfer from the elementary to middle school level, and from the middle to high school level. In the future, researchers could investigate the growth trajectory in the next three years to see whether even more future eighth-grade students achieve at higher performance levels since the current group of fifth-grade students appear to have a better math foundation, as indicated by their performance.

To answer the second research question, we included district-level characteristics in the growth model. The results indicated that Grade 5 and 8 students' math performance at three performance levels was consistently and significantly impacted by five district-level characteristics: economically challenged student percentage, EL percentage, student mobility rate, principal years of experience, and teacher turnover rate. Our findings are consistent with previous studies that indicated the percentage of economically challenged students [12,14], student mobility rate [33], and teacher turnover rate [20] had a significant negative correlation with students' academic performance. Furthermore, the instability and disruption to the learning environment caused by higher rates of teacher turnover and student mobility also negatively impacted students' math performance. It is worth noting that after considering these district-level characteristics, time remained a statistically 
significant predictor. One possible reason is that once students leave elementary and enter middle school, with its more differentiated math classes, lower-performing students are able to achieve grade-level performance. Another potential explanation is that in Texas, like other states, math performance is tied to students' retention and advancement [46]. However, in recent years, the state of Texas has implemented a new school accountability policy that is supposed to make it easier for the state to identify and intervene in lowperforming schools and school districts. Therefore, schools must strive to ensure that all students are at least performing at grade level in math, so they can advance.

In addition, we noticed that there was a significant positive correlation between EL student percentage and student math performance, which is different from previous studies that suggested limited English proficiency has a negative impact on students' academic performance in science [38] and reading [47]. One of the possible reasons is that language might be less influential on math performance compared to its impact on reading, science, and social science [48]. Unlike reading and other subjects that require higher English language proficiency and skills, math emphasizes cognitive abilities, such as reasoning and working memory $[49,50]$.

We also found that teacher years of experience only impacted students rated approaching grade level in the STAAR math test. In contrast, other district characteristics, such as student mobility rate, EC percentage, and teacher turnover, had an impact on student math learning across all performance levels. Our findings are consistent with previous findings that high-poverty schools struggle in supporting their students' success in academic learning [13]. Furthermore, this finding is also aligned with previous investigations showing that student mobility is negatively associated with student achievement [51]. Based on our findings, we suggest that school districts should endeavor to retain as many effective teachers as possible to build stability, collegiality, and relational trust among teachers [29]. School districts can provide incentive structures to retain teachers who might leave [29] or ongoing professional development, mentoring, and coaching to empower teachers instructional capacity [52], and further enhance teacher quality of instruction [38,47]. Future studies could take a more comprehensive view of the mechanisms by which student mobility and teacher turnover rates influence student achievement.

Based on our observations, Texas has successfully supported students in math learning in the past three years, even with a high percentage of EC students and high rates of student mobility and teacher turnover. Therefore, we suggest that administrators and policymakers in Texas continue to support districts, schools, and teachers in promoting student math achievement. Student-level factors, such as student poverty and mobility, are beyond the schools' control. However, with more educational resources, professional development opportunities, and incentive structures, one significant negative district-level factor-teacher turnover-might be decreased, which could benefit students at all performance levels.

\section{Conclusions}

Based on our findings, we concluded that Texas school districts improved in the percentage of students who approached, met, and mastered grade-level performance on the STAAR math test. Significant positive factors included the percentage of English learner students and principal years of experience; significant negative factors were the percentage of economically challenged students, student mobility rate, and teacher turnover rate. Although students' economic status and mobility rate were found to negatively impact their academic achievement, researchers and educators have no control over these factors. What researchers and teachers can do is to investigate solutions to these issues and to provide the best instruction possible, respectively. Therefore, it is up to school and district administrators and the state to provide teachers with support. Classroom teachers will inevitably come and go in any given district, but there are steps school leaders can take to attract, retain, and invest in effective teachers. In addition, leadership training programs should be provided to school principals to enhance leadership practices and serve their needs in meeting accountability requirements. 
Author Contributions: Conceptualization: S.T. and Z.W.; methodology: S.T. and Z.W.; investigation: S.T. and Z.W.; data curation, writing-original draft preparation: S.T. and Z.W.; formal analysis and visualization: S.T. and Z.W.; writing - review and editing: K.L.S.-J. All authors have read and agreed to the published version of the manuscript.

Funding: This research received no external funding.

Data Availability Statement: Our data were collected from publicly available sources, including the Texas Assessment Management System (TAMS) and Texas Education Agency (TEA) annual reports. That data is available on the following websites: https://txreports.emetric.net/ and https://rptsvr1 .tea.texas.gov/cgi/sas/broker.

Conflicts of Interest: The authors declare no conflict of interest.

\section{References}

1. English, L.D. Advancing Elementary and Middle School STEM Education. Int. J. Sci. Math. Educ. 2017, 15, 5-24. [CrossRef]

2. Maass, K.; Geiger, V.; Ariza, M.R.; Goos, M. The Role of Mathematics in interdisciplinary STEM education. ZDM 2019, 51, 869-884. [CrossRef]

3. Martín-Páez, T.; Aguilera, D.; Perales-Palacios, F.J.; Vílchez-González, J.M. What are we talking about when we talk about STEM education? A review of literature. Sci. Educ. 2019, 103, 799-822. [CrossRef]

4. Schmidt, W.H.; Houang, R.T. Lack of focus in the mathematics curriculum: Symptom or cause. In Lessons Learned: What International Assessments Tell Us about Math Achievement; Loveless, T., Ed.; Brookings Institution Press: Washington, DC, USA, 2007; pp. 65-84.

5. Fitzallen, N. STEM education: What does mathematics have to offer? In Mathematics Education in the Margins; Marshman, M., Geiger, V., Bennison, A., Eds.; MERGA: Sunshine Coast, Australia, 2015; pp. 237-244.

6. Clements, D.H.; Sarama, J. Math, Science, and Technology in the Early Grades. Futur. Child. 2016, 26, 75-94. [CrossRef]

7. English, L.D. Advancing Mathematics Education Research within a STEM Environment. In Research in Mathematics Education in Australasia 2012-2015; Makar, K., Dole, S., Visnovska, J., Goos, M., Bennison, A., Fry, K., Eds.; Springer: Singapore, 2016; pp. 353-371.

8. Schwerdt, G.; West, M.R. The impact of alternative grade configurations on student outcomes through middle and high school. J. Public Econ. 2013, 97, 308-326. [CrossRef]

9. Goldstein, S.E.; Boxer, P.; Rudolph, E. Middle School Transition Stress: Links with Academic Performance, Motivation, and School Experiences. Contemp. Sch. Psychol. 2015, 19, 21-29. [CrossRef]

10. Simpkins, S.D.; Davis-Kean, P.; Eccles, J.S. Math and science motivation: A longitudinal examination of the links between choices and beliefs. Dev. Psychol. 2006, 42, 70-83. [CrossRef]

11. Singh, K.; Granville, M.; Dika, S. Mathematics and science achievement: Effects of motivation, interest, and academic engagement. J. Educ. Res. 2002, 95, 323-332. [CrossRef]

12. Slavin, R.E.; Lake, C.; Groff, C. Effective Programs in Middle and High School Mathematics: A Best-Evidence Synthesis. Rev. Educ. Res. 2009, 79, 839-911. [CrossRef]

13. Hussar, B.; Zhang, J.; Hein, S.; Wang, K.; Roberts, A.; Cui, J.; Smith, M.; Bullock Mann, F.; Barmer, A.; Dilig, R. The Condition of Education 2020; NCES 2020-144; National Center for Education Statistics: Washington, DC, USA, 2020.

14. Baird, K. Class in the classroom: The relationship between school resources and math performance among low socioeconomic status students in 19 rich countries. Educ. Econ. 2012, 20, 484-509. [CrossRef]

15. Caro, D.H. Socio-economic status and academic achievement trajectories from childhood to adolescence. Can. J. Educ. 2009, 32, $558-590$.

16. Southworth, B. Am I Rich Enough to Do Well in Math? Math Test Scores and Socio-Economic Status. Master's Thesis, Wichita State University, Wichita, KS, USA, 2006.

17. Mosqueda, E. Compounding inequalities: English proficiency and tracking and their relation to mathematics performance among Latina/o secondary school youth. J. Urban Math. Educ. 2010, 3, 57-81.

18. Kuenzi, J.J. Science, Technology, Engineering, and Mathematics (STEM) Education: Background, Federal Policy, and Legislative Action; Congressional Research Service Reports: Washington, DC, USA, 2008.

19. Tella, A. Teacher variables as predictors of academic achievement of primary school pupils' mathematics. Int. Electron. J. Elem. Educ. 2017, 1, 16-33.

20. Curtis, C. Why do they choose to teach-and why do they leave? A study of middle school and high school mathematics teachers. Education 2012, 132, 779-789.

21. Texas Administration Code. In Texas Essential Knowledge and Skills for Math; Subchapter A. Elementary; Texas Education Agency: Austin, TX, USA, 2012; Chapter 111; Available online: http:/ / ritter.tea.state.tx.us/rules/tac/chapter111/ch111a.html (accessed on 15 October 2020).

22. Texas Administration Code. In Texas Essential Knowledge and Skills for Math; Subchapter B. Middle School; Texas Education Agency: Austin, TX, USA, 2012; Chapter 111; Available online: http://ritter.tea.state.tx.us/rules/tac/chapter111/ch111b.html (accessed on 15 October 2020). 
23. Texas Education Agency. STAAR Performance Level Descriptors; Texas Education Agency: Austin, TX, USA, 2019. Available online: https://tea.texas.gov/student-assessment/testing/staar/staar-performance-level-descriptors (accessed on 23 November 2020).

24. Heller, S.B.; Shah, A.K.; Guryan, J.; Ludwig, J.; Mullainathan, S.; Pollack, H.A. Thinking, Fast and Slow? Some Field Experiments to Reduce Crime and Dropout in Chicago. Q. J. Econ. 2017, 132, 1-54. [CrossRef] [PubMed]

25. Farooq, M.S.; Chaudhry, A.H.; Shafiq, M.; Berhanu, G. Factors affecting students' quality of academic performance: A case of secondary school level. J. Qual. Technol. Manag. 2011, 7, 1-14.

26. Abedi, J.; Herman, J. Assessing English language learners' opportunity to learn mathematics: Issues and limitations. Teach. Coll. Rec. 2010, 112, 723-746.

27. Cook-Harvey, C.M.; Darling-Hammond, L.; Lam, L.; Mercer, C.; Roc, M. Equity and ESSA: Leveraging Educational Opportunity through the Every Student Succeeds Act. Learning Policy Institute. 2016. Available online: https://nces.ed.gov/ nationsreportcard/state/state_differences.aspx (accessed on 18 October 2020).

28. Ladd, H.F.; Sorensen, L.C. Returns to Teacher Experience: Student Achievement and Motivation in Middle School. Educ. Financ. Policy 2017, 12, 241-279. [CrossRef]

29. Ronfeldt, M.; Loeb, S.; Wyckoff, J. How Teacher Turnover Harms Student Achievement. Am. Educ. Res. J. 2013, 50, 4-36. [CrossRef]

30. Dhuey, E.; Smith, J. How important are school principals in the production of student achievement? Can. J. Econ. 2014, 47, 634-663. [CrossRef]

31. Huff, T.S.; Brockmeier, L.L.; Leech, D.W.; Martin, E.P.; Pate, J.L.; Siegrist, G. Principal and school-level effects on student achievement. Natl. Teach. Educ. J. 2011, 4, 67-79.

32. Koç, N.; Çelik, B. The Impact of Number of Students per Teacher on Student Achievement. Procedia Soc. Behav. Sci. 2015, 177, 65-70. [CrossRef]

33. Parke, C.S.; Kanyongo, G.Y. Student Attendance, Mobility, and Mathematics Achievement in an Urban School District. J. Educ. Res. 2012, 105, 161-175. [CrossRef]

34. Zientek, L.R.; Ozel, Z.E.Y.; Fong, C.J.; Griffin, M. Student Success in Developmental Mathematics Courses. Community Coll. J. Res. Pr. 2013, 37, 990-1010. [CrossRef]

35. The Nation's Report Card. State Performance Compared to the Nation; National Center for Education Statistics: Washington, DC, USA, 2017. Available online: https: / / www.nationsreportcard.gov / profiles / stateprofile?chort=1\&sub=MAT\&sj=AL\&sfj=NP\&st= MN\&year=2017R3 (accessed on 19 November 2020).

36. Texas Education Agency. Texas Academic Performance Report; 2018-2019 State STAAR Performance; Texas Education Agency: Austin, TX, USA, 2019. Available online: https://rptsvr1.tea.texas.gov/cgi/sas/broker?_service=marykay\&year4=2019\&year2=1 9\&_debug=0\&single $=$ N\&batch=N\&app $=$ PUBLIC\&title=2019+Texas + Academic + Performance + Reports\&_program $=$ perfrept. perfmast.sas\&ptype $=\mathrm{H} \&$ paper $=\mathrm{N} \&$ level=state\&search=campname\&namenum $=\&$ prgopt=2019\%2Ftapr\%2Fpaper_tapr.sas $($ ac cessed on 19 November 2020).

37. Anderson, P.B. Differences in Mathematics and Science Performance by Economic Status, Gender, and Ethnicity/Race: A Multiyear Texas Statewide Study. Ph.D. Dissertation, Sam Houston State University, Huntsville, TX, USA, 2016.

38. Wang, Z.; Tang, S.; Sutton-Jones, K.L. Texas Rural vs. Nonrural School District Student Growth Trajectories on a High-Stakes Science Exam: A Multilevel Approach. Soc. Sci. 2019, 8, 166. [CrossRef]

39. Texas Education Agency. Texas Public School Districts Categorized by Type, 2016-2017; Texas Education Agency: Austin, TX, USA, 2017. Available online: https:/ / tea.texas.gov/reports-and-data/school-data/district-type-data-search/texas-public-schooldistricts-categorized-by-type-2016-17 (accessed on 19 November 2020).

40. Texas Education Agency. Texas Administrative Code (TAC) §89.1225; Texas Education Agency: Austin, TX, USA, 2012. Available online: https: / / texreg.sos.state.tx.us /public/readtac\$ext.TacPage?sl=R\&app=2\&p_dir=\&p_rloc=156468\&p_tloc=\&p_ploc=\&pg= $1 \&$ p_tac $=156468 \& \mathrm{ti}=19 \& \mathrm{pt}=2 \& \mathrm{ch}=89 \& \mathrm{rl}=1225 \& \mathrm{dt}=05 / 28 / 2012 \& z \_c h k=\& z \_c o n t a i n s=($ accessed on 19 November 2020).

41. Texas Education Agency. 2016-2017 Texas Education Data Standards; Texas Education Agency: Austin, TX, USA, 2017. Available online: http:/ / castro.tea.state.tx.us/tsds/teds/2017A/v2.1/teds-ds2.4.pdf (accessed on 19 November 2020).

42. Texas Education Agency. Glossary. In 2016-17 Texas Academic Performance Report; Texas Education Agency: Austin, TX, USA, 2017. Available online: https://tea.texas.gov/sites/default/files/TAPR\%20Glossary_2017_October.pdf (accessed on 12 November 2020).

43. Kwok, O.-M.; Underhill, A.T.; Berry, J.W.; Luo, W.; Elliott, T.R.; Yoon, M. Analyzing longitudinal data with multilevel models: An example with individuals living with lower extremity intra-articular fractures. Rehabil. Psychol. 2008, 53, 370-386. [CrossRef]

44. Chen, H.; Cohen, P. Using individual growth model to analyze the change in quality of life from adolescence to adulthood. Health Qual. Life Outcomes 2006, 4, 10. [CrossRef]

45. Kwok, O.-M.; Luo, W.; West, S.G. Using Modification Indexes to Detect Turning Points in Longitudinal Data: A Monte Carlo Study. Struct. Equ. Model. A Multidiscip. J. 2010, 17, 216-240. [CrossRef]

46. Texas Education Agency. Grade-Level Retention and Student Performance in Texas Public Schools, 2018-2019; Texas Education Agency: Austin, TX, USA, 2019. Available online: https://tea.texas.gov/sites/default/files/retention_student_performance_2018-19.pdf (accessed on 23 November 2020).

47. Tong, F.; Irby, B.J.; Lara-Alecio, R.; Koch, J. Integrating Literacy and Science for English Language Learners: From Learning-toRead to Reading-to-Learn. J. Educ. Res. 2014, 107, 410-426. [CrossRef] 
48. Abedi, J. The No Child Left Behind Act and English Language Learners: Assessment and Accountability Issues. Educ. Res. 2004, 33, 4-14. [CrossRef]

49. Hakuta, K.; Santos, M. Co-Chairs. Commissioned papers on language and literacy issues in the Common Core State Standards and Next Generation Science Standards. Teach. Dev. 2012, 94, 1-145.

50. Moschkovich, J. Principles and guidelines for equitable mathematics teaching practices and materials for English language learners. J. Urban Math. Educ. 2013, 6, 45-57.

51. U.S. Government Accountability Office. Many Challenges Arise in Educating Students Who Change Schools Frequently. 2010. Available online: http:/ / www.gao.gov/assets/320/312480.pdf (accessed on 28 November 2020).

52. Stosich, E.L. Building teacher and school capacity to teach to ambitious standards in high-poverty schools. Teach. Teach. Educ. 2016, 58, 43-53. [CrossRef] 